\title{
Assessment of spawning of Atlantic bluefin tuna farmed in the western Mediterranean Sea
}

\author{
Antonio Medina ${ }^{1, *}$, Guillermo Aranda ${ }^{1}$, Silvia Gherardii ${ }^{1}$, Agustín Santos ${ }^{1}$, \\ Begonya Mèlich ${ }^{2}$, Manuel Lara ${ }^{2}$ \\ ${ }^{1}$ University of Cádiz, Department of Biology (Zoology), Faculty of Marine and Environmental Sciences, \\ Campus de Excelencia Internacional del Mar (CEI·MAR), 11510 Puerto Real, Cádiz, Spain \\ ${ }^{2}$ Grup Balfegó, Pol. Ind. edifici ‘Balfegó', 43860 L'Ametlla de Mar, Tarragona, Spain
}

\begin{abstract}
Mediterranean tuna farms account for $>60 \%$ of the eastern Atlantic bluefin tuna (ABFT) catch quota. Besides the direct impact of purse seining on wild stocks, ABFT farming practices may have environmental implications that are still poorly known. An unexplored potential source of interactions of ABFT farms with wildlife is the release of eggs into the environment in places other than spawning grounds. Purse seine-caught ABFT schools are known to spawn in towing cages as they are transported to farms. We show here that farmed ABFT are also capable of spawning during at least 2 subsequent reproductive seasons following their capture. The reproductive potential of ABFT commercial stocks was investigated in a farm located in the western Mediterranean Sea from 2012 through 2014, using occurrence and number of postovulatory follicles as proxies of spawning fraction and realised batch fecundity, respectively. Although the spawning fraction among farmed fish was lower than that in the wild, the mean fecundity of captive spawners was similar to that of wild fish; consequently, the number of fertile eggs released from grow-out cages is thought to be significant. Larvae hatched from eggs spawned in farms are likely to grow and join wild-born ABFT juveniles that use nearshore areas of the western Mediterranean as foraging grounds. Depending on the volume of fish ranched for $>1 \mathrm{yr}$ and the larval survival rate in the region, the escape through spawning may have a significant impact on the ecosystem and could affect recruitment, thus influencing the population dynamics of ABFT in the Mediterranean Sea.
\end{abstract}

KEY WORDS: Thunnus thynnus - Bluefin tuna farms - Reproductive maturation - Spawning · Fecundity Egg production

\section{INTRODUCTION}

Since the 1990s, farming of Atlantic bluefin tuna (ABFT) Thunnus thynnus (Linnaeus, 1758), in the Mediterranean Sea has become a profitable activity which relies on the capture of live fish from the wild (Ottolenghi 2008, Mylonas et al. 2010, Vitalini et al. 2010, Metian et al. 2014). ABFT are caught in spring and summer by purse-seine fleets and transported to offshore sea cages for fattening/farming over 4 mo to 1-2 yr. These capture-based aquaculture practices have received strong criticism, as they can negatively affect the natural resources (Sumaila \& Huang 2012).

${ }^{*}$ Corresponding author: antonio.medina@uca.es
In addition to the direct impact of purse seining on wild populations, ABFT farming may have a suite of significant ecological implications that are still poorly understood. Most studies on environmental impacts of tuna farms have been focused on the effects of waste discharged from the cages (e.g. Vezzulli et al. 2008, Piedecausa et al. 2010, Sarà et al. 2011, Vizzini \& Mazzola 2012, Moraitis et al. 2013, Mangion et al. 2014). However, very little data currently exist regarding other interactions between wildlife and ABFT farming activities. A widespread phenomenon that has been identified recently is the strong attracting effect of Mediterranean ABFT farms on wild individ-

(C) The authors 2016. Open Access under Creative Commons by Attribution Licence. Use, distribution and reproduction are unrestricted. Authors and original publication must be credited. 
uals, which could cause alterations in their schooling behaviour and migratory patterns (Arechavala-López et al. 2015).

Another source of potential interactions with wildlife is the production of eggs by farmed ABFT. Although spawning has been observed in commercial cages, no investigation has been conducted to monitor and assess the reproductive performance of ABFT in farms. However, given the substantial proportion $(>60 \%)$ of the eastern ABFT total allowable catch eventually absorbed by purse-seine fleets that supply live fish to tuna farms (Ortiz 2015), it is likely that the number of eggs leaked from the cages to the environment is significant. Therefore, the assessment of the egg production capacity of farm stocks is worthy of consideration with a view to improving our perception of potential impacts of the ABFT fattening/farming industry. Bluefin tuna held in captivity undergo physiological impairment that results in significant reduction of their reproductive capacity (Mylonas et al. 2007). However, experiments carried out on cage-reared ABFT have shown that most of the individuals treated with implants loaded with gonadotropin releasing hormone agonist (GnRHa) recovered the capacity to mature and release fertile gametes (Corriero et al. 2007, 2009, Mylonas et al. 2007, de la Gándara et al. 2010, De Metrio et al. 2010, Aranda et al. 2011, Rosenfeld et al. 2012). A small proportion of the untreated fish in the experimental broodstock were likewise capable of spawning as early as $1 \mathrm{yr}$ after their capture from the wild, showing fecundity rates that were similar to those of GnRHa-treated individuals (Corriero et al. 2007, Aranda et al. 2011). Uninduced spawning has also been observed in an experimental ABFT stock maintained in captivity for $1 \mathrm{yr}$ and transported to the Balearic spawning grounds during the reproductive season (Gordoa \& Carreras 2014).

In this study, we assessed the short-term reproductive performance of farmed ABFT by gonad histology analysis during the breeding season. The occurrence and number of postovulatory follicles (POFs) in the ovaries were estimated to determine the female spawning fraction and batch fecundity. Such estimates can be used to calculate the egg production capacity of commercial stocks.

\section{MATERIALS AND METHODS}

\section{Animals and farming conditions}

ABFT were caught by purse seining around the Balearic Islands (Spain) in June 2010, 2012 and 2013.
They were transported to grow-out floating cages in the farming facilities of Grup Balfegó, located $4 \mathrm{~km}$ off L'Ametlla de Mar (Tarragona, NE Spain; Fig. 1). The holding cages were circular $(50 \mathrm{~m}$ in diameter and $30 \mathrm{~m}$ deep) or elliptical (120 m long, $60 \mathrm{~m}$ wide, $30 \mathrm{~m}$ deep) and were moored in water of a total depth of $50 \mathrm{~m}$. The initial stocking density was $\sim 3 \mathrm{~kg} \mathrm{~m}^{-3}$. After an adaptation period of a few weeks, the fish were fed to satiation $5 \mathrm{~d} \mathrm{wk}^{-1}$ with defrosted baitfish, mostly mackerel. The initial ratio of bait supplied per total ABFT weight was $\sim 8 \%$ in summer and decreased gradually to $\sim 2 \%$ in winter. The sea surface water temperature (SST) was recorded daily from each cage. SST ranged from $11.6^{\circ} \mathrm{C}$ (February 2013) to $28.3^{\circ} \mathrm{C}$ (August 2012).

Systematic experimental sampling was impracticable, as the harvesting dates were fully dependent on the market demand. Harvesting took place between 06:00 and 08:00 h (UTC). Total body weight (BW, to the nearest $0.01 \mathrm{~kg}$ ) and straight fork length $(\mathrm{FL}$, to the nearest $1 \mathrm{~cm})$ were recorded for each fish as they were harvested. Gonads were sampled from late May to early August in order to span the natural reproductive season of ABFT in the western Mediterranean Sea (Heinisch et al. 2008). Gonad weight (GW) was recorded to the nearest $0.01 \mathrm{~kg}$, and the gonadosomatic index (GSI) was calculated as GSI = $100 \mathrm{GW} \mathrm{BW}^{-1}$. The ovarian volume (OV) was estimated from the ovarian mass according to the equation: OV $=0.9174$ GW (Medina et al. 2007).

All fish used in this study far exceeded $135 \mathrm{~cm}$ in FL, which is the size at which $100 \%$ of eastern ABFT

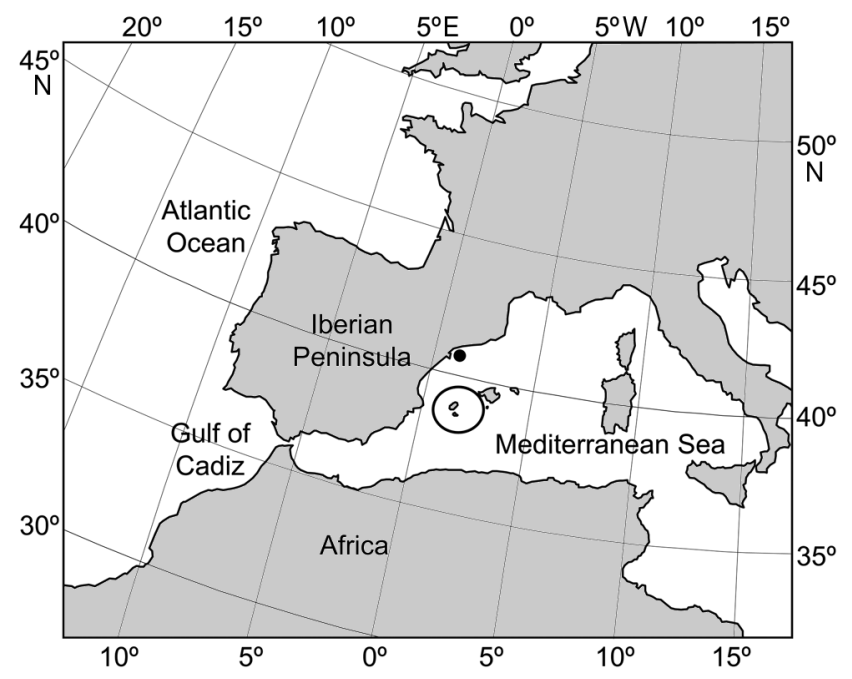

Fig. 1. Approximate location of the Atlantic bluefin tuna Thunnus thynnus farm where the study was conducted (black dot) and the fishing grounds where the fish were caught (circle) 
are assumed to attain sexual maturity (Corriero et al. 2005). This, added to the fact that Mediterranean ABFT purse seiners primarily target schools of spawners, suggests that all the individuals examined were sexually mature.

\section{Histology and functional classification of gonads}

A piece of tissue was removed from the central part of one of the gonads and fixed in $10 \%$ phosphatebuffered formalin $(4 \%$ formaldehyde in $0.1 \mathrm{M}$ phosphate buffer, $\mathrm{pH}$ 7.2). The tissue samples were then washed in buffer, dehydrated in ethyl alcohol, cleared in xylene and embedded in paraffin. Serial $10 \mu \mathrm{m}$ sections of the ovaries were stained with haematoxylin-VOF (Gutiérrez 1967) and photographed on a light microscope Nikon eclipse $\mathrm{Ci}{ }^{\circledR}$ equipped with a Jenoptik ProgRes ${ }^{\circledR}$ CT5 digital camera. Histological sections of the testes were stained with haematoxylineosin.

Following Schaefer (1998), female ABTF were classified into 4 reproductive functional stages (Table 1), based on the most advanced group of ovarian follicles and the extent of atresia (for atretic states, see Hunter \& Macewicz 1985a). The ovaries of resting (R) females contain only unyolked and/or early yolked oocytes and no sign of atresia. Active nonspawning (ANS) females show large yolked oocytes and minor $(<50 \%)$, if any, $\alpha$ atresia. The active spawning (AS) condition is characterized by signs of either imminent spawning (presence of migratory-nucleus and/or hydrated oocytes) or recent spawning (evidenced by postovulatory follicles). Inactive mature (IM) females have entered regression following the end of reproductive activity, hence the ovaries contain either previtellogenic or early yolked oocytes plus $\alpha$ and/or $\beta$ atresia, or advanced yolked oocytes plus major $(>50 \%) \alpha$ atresia (Fig. 2). Among females, the spawning fraction was calculated as the proportion of mature fish with POFs (Hunter \& Macewicz 1985b).

Three or 4 distinct developmental stages have been identified from gonad histology in captive bluefin tuna males (e.g. Corriero et al. 2007, Sawada et al. 2007, Seoka et al. 2007). The male reproductive stages distinguished in our samples are shown in Table 2, which is based on Corriero et al. (2007). In fish at late spermatogenesis (LS), the germinal epithelium of the testes consists mainly of cysts composed of spermatids and spermatozoa, although spermatocyte and spermatid cysts are also present; the lumen of the seminiferous lobules and central ducts becomes filled with sperm. The testes of spent (S) males lack germinal cysts, and the lumen of the seminiferous lobules appears completely empty or shows scarce, loose residual sperm (Fig. 3).

\section{Stereology}

POFs were quantified by the physical disector method of Sterio (1984) adapted to fish ovarian samples (Aragón et al. 2010, Aranda et al. 2011, Ganias et al. 2014). The disector pairs consisted of 2 consecutive sections (referred to as reference and look-up sections) that were 40 or $60 \mu \mathrm{m}$ apart (depending on the POF size in the histological sample). Three counting frames of $9.78 \mathrm{~mm}^{2}$ were used per disector pair, and the total number of counting frames used per ovary was 18. POFs that appeared in the counting frame on the reference section, but not in the look-up section, were counted. When POFs touched the left or bottom lines of the frame, they were not counted. Counts were also made in the opposite direction. The volume number density of POFs was estimated according to the formula: $\mathrm{N}_{\mathrm{V}}=\Sigma Q^{-}(2 \Sigma P \text { a/f } h)^{-1}$, where $\Sigma Q^{-}$is the total number of POFs counted, $\Sigma P$ is the number of disectors used per ovary (18), $h$ is the disector thickness (40 or $60 \mu \mathrm{m})$, and $a / f$ is the area of the working frame $\left(9.78 \mathrm{~mm}^{2}\right)$. During histological processing, tissue

Table 1. Classification of Atlantic bluefin tuna Thunnus thynnus females in 4 different reproductive stages based on histological features according to Schaefer (1998). POF: postovulatory follicle

\begin{tabular}{|lll}
\hline Stage & Histological features & Number of fish \\
\hline Resting $^{\text {a }(\mathrm{R})}$ & Unyolked or early yolked oocytes and no atresia & 8 \\
Active nonspawning (ANS) & Advanced yolked oocytes and no atresia or minor $(<50 \%) \alpha$ atresia & 28 \\
Active spawning (AS) & Avanced yolked oocytes and no or minor $\alpha$ atresia plus POFs and/or & 18 (1 with no POF) \\
& migratory-nucleus oocytes & 4 \\
Inactive mature (IM) & $\begin{array}{c}\text { Previtellogenic or early yolked oocytes plus } \alpha \text { and/or } \beta \text { atresia, or } \\
\text { advanced yolked oocytes plus major }(>50 \%) \alpha \text { atresia }\end{array}$ & 4 \\
a Referred to as 'immature' in the original classification of Schaefer (1998) & \\
\hline
\end{tabular}



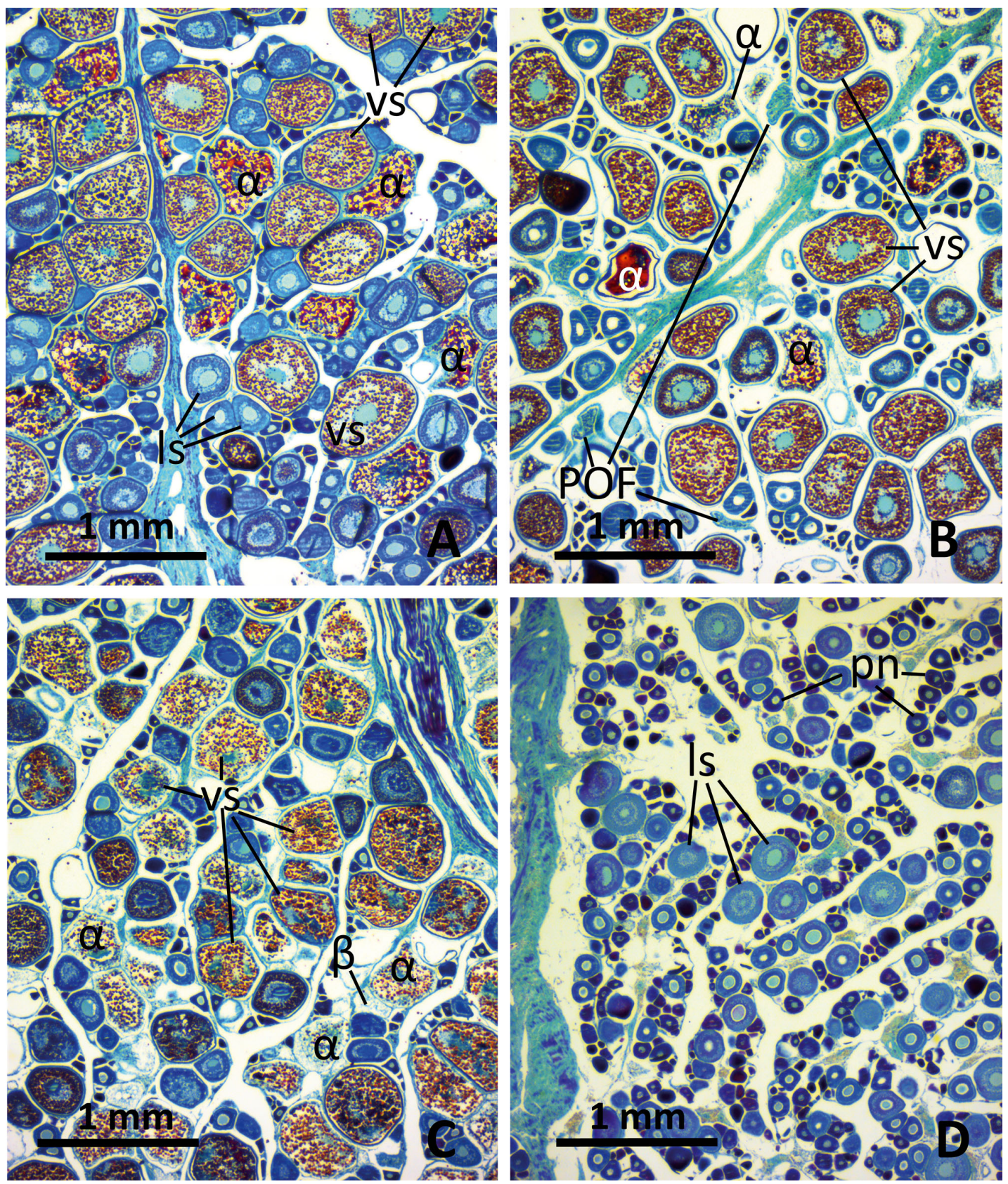

Fig. 2. Micrographs of Atlantic bluefin tuna Thunnus thynnus ovaries at the 4 developmental stages identified in this study: (A) active nonspawning (ANS); (B) active spawning (AS); (C) inactive mature (IM); (D) resting (R). ls: lipid-stage oocyte; pn: perinucleolar oocyte; POF: postovulatory follicle; vs: vitellogenic oocyte; $\alpha$ : $\alpha$-atretic follicle; $\beta$ : $\beta$-atretic follicle. HaematoxylinVOF staining

samples experience a mean volume loss of $34.8 \%$ (Knapp et al. 2014). Therefore, a correction factor was applied to account for sample shrinkage. The total number of POFs (realised batch fecundity) was thus calculated as $\mathrm{N}=0.652 \cdot \mathrm{OV} \cdot \mathrm{N}_{\mathrm{V}}(\mathrm{OV}$ : ovarian volume), and the relative realised batch fecundity as the number of POFs ${ }^{-1} \mathrm{BW}$.

\section{Statistical analysis}

Differences of means between groups of data were analysed using either Student's $t$-test or ANOVA followed by Tukey's HSD post hoc test. In order to integrate data of Gregorian dates into statistical analysis, they were converted to days of the year, rang- 
Table 2. Classification of Atlantic bluefin tuna Thunnus thynnus males in the 2 different reproductive stages identified in this study on the basis of histological criteria according to Corriero et al. (2007)

\begin{tabular}{|llc|}
\hline Stage & Histological features & Number of fish \\
\hline $\begin{array}{ll}\text { Late spermato- } \\
\text { genesis (LS) }\end{array}$ & $\begin{array}{l}\text { Germinal epithelium of the testicular lobes containing cysts of developing male germ } \\
\text { system of ducts filled with spermatozoa }\end{array}$ & 19 \\
Spent (S) & $\begin{array}{l}\text { Germinal epithelium devoid of germinal cysts, and consisting mostly of spermatogonia; } \\
\text { lumina of seminiferous lobules completely empty or showing loose residual sperm }\end{array}$ & 4 \\
\hline
\end{tabular}

ing from 1 to 366 for 2012, and 1 to 365 for 2013 and 2014. Relationships between continuous variables were assessed by linear regression and bivariate Pearson's correlation analyses. A significance level of $\alpha=0.05$ was considered in all tests. The statistical analyses were performed using SPSS version 15.0 and R Statistical Software version 3.2.0 (R Core Team 2015). Collective data are expressed as means \pm SD.

\section{RESULTS}

\section{Animals and morphometry}

Eighteen fish (all females) were sampled in 2012, of which 17 had been captured in 2010 and 1 in 2012. In 2013, 22 females and 7 males sourced from the wild in 2012 and 2013 were examined. All tuna sampled in 2014 (18 females and 17 males) were captured in 2013, with the exception of 1 male which had been caught in the previous month in 2014 (see Table S1 in the Supplement at www.int-res.com/articles/suppl/ q008p089_supp.pdf).

ABFT size ranged from 144 to $266 \mathrm{~cm} \mathrm{FL,} \mathrm{and} \mathrm{from}$ 63 to $453 \mathrm{~kg}$ BW. The mean ( \pm SD) size of the females analysed in $2012(163.50 \pm 13.46 \mathrm{~cm})$ was significantly lower than that of the females sampled in the 2 subsequent years $(211.45 \pm 9.92 \mathrm{~cm}$ and $212.22 \pm$ $15.05 \mathrm{~cm}$; ANOVA, $F_{2,55}=88.56, \mathrm{p}<0.001$, followed by Tukey's HSD test, $\mathrm{p}<0.001)$. The mean size of the males was similar in $2013(223.17 \pm 13.47 \mathrm{~cm})$ and $2014\left(220.59 \pm 22.94 \mathrm{~cm} ; t_{21}=0.26, \mathrm{p}=0.80\right)$.

\section{Histology}

The majority (12) of the 18 tuna sampled in 2012 (all females) were classified as ANS; 4 of these fish (ANS* in Table S1) were entering the regression phase as they showed advanced yolked oocytes and the proportion of $\alpha$ atretic oocytes was close to $50 \%$ (>40\%). One of the fish was at the regenerating phase at the time of sampling (6 August); 2 individuals that were sacrificed in late July were IM, and the remaining 3 fish, which were sampled between 11 June and 12 July, were at the AS stage (Fig. 4). Spawning occurred at SSTs between 21.5 and $24.3^{\circ} \mathrm{C}$ (Table S1). The estimated spawning fraction was 0.2 (Fig. 4).

Five of the 22 females analysed in 2013 were sampled only 1 mo after their capture from the wild. One of them, sacrificed on 10 July, was IM, whereas the 4 others, which were sampled in late July, had completed ovarian regression and were therefore in the $\mathrm{R}$ stage. Among the fish that had spent over $1 \mathrm{yr}$ in captivity, 7 were AS females, which were harvested between 10 June and 23 July. One of them had no POFs but did contain migratory-nucleus stage oocytes. Spawning occurred at SSTs between 21.47 and $27.0^{\circ} \mathrm{C}$, with the exception of 1 individual sampled on 10 June 2013 at $17.2^{\circ} \mathrm{C}$ SST. Nine females were found at the ANS stage, 7 of which were nearing the regression phase (close to $50 \% \alpha$ atresia). The remaining 2 females held in captivity for over $1 \mathrm{yr}$ (sampled in late July and early August) were R (Fig. 4, Table S1). The estimated spawning fraction was 0.4 (Fig. 4).

The males harvested on 5 June and 10 July 2013, 1 yr after their capture, were found to be at the LS stage. The 4 males sampled in late July had been caught during the year's fishing season 1 mo earlier, and were all considered S (Table S1).

In 2014, the 8 females classified as AS were sampled between 9 June and 14 July. Spawning occurred at SST between 20.3 and $22.5^{\circ} \mathrm{C}$. Another 8 females were classified as ANS; 1 of them was apparently in the transition towards the IM stage. One IM female was harvested on 31 July, and the only R individual was sampled on 4 August (Fig. 4, Table S1). The estimated spawning fraction was 0.5 (Fig. 4).

All males appeared to be reproductively active (LS stage) throughout the sampling period (30 May to 4 August; Table S1).

We found significant differences in GSI values among different histological categories in both males and females (ANOVA, $F_{3,54}=9.38, \mathrm{p}<0.001$ ). GSI was significantly lower in $\mathrm{R}$ females (mean $\pm \mathrm{SD}$ : 

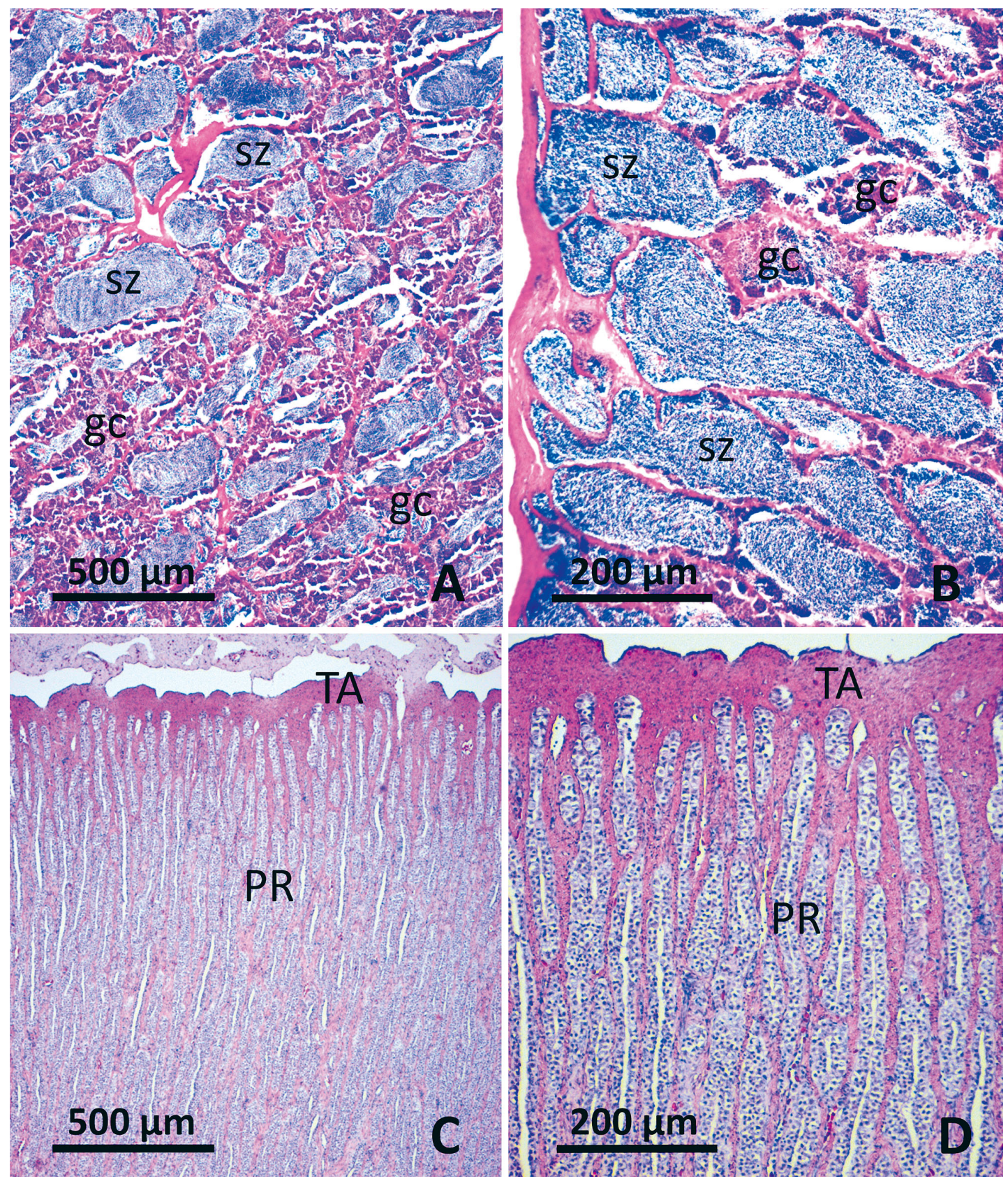

Fig. 3. Micrographs of Atlantic bluefin tuna Thunnus thynnus testes at the 2 maturation stages recognised in this study: (A) and (B) late spermatogenic stage (LS); (C) and (D) spent (S). gC: germinal cyst; PR: peripheral region of the testis showing lobules devoid of germinal cysts and spermatozoa; sz: spermatozoa; TA: tunica albuginea. Haematoxylin-eosin staining

$1.06 \pm 0.31)$ than in ANS $(3.23 \pm 1.06)$ and AS females $(3.02 \pm 1.01)$ (Tukey's HSD test, $\mathrm{p}<0.001)$, which showed similar GSI values, whereas IM females $(2.73 \pm 1.74)$ had intermediate values that did not significantly differ from the other 3 categories. The mean GSI was significantly higher in LS males $(1.99 \pm 1.21)$ than in S males $(0.31 \pm 0.11)(t$-test assuming unequal variances, $\left.t_{16}=5.45, \mathrm{p}<0.001\right)$.

\section{Stereology}

The mean $( \pm \mathrm{SD})$ realised batch fecundities estimated from the number of POFs (in millions of eggs) were $2.07 \pm 1.69$ (year 2012), $8.54 \pm 5.28$ (2013) and $12.71 \pm 5.98$ (2014). ANOVA indicated significant differences among the 3 groups of samples $\left(F_{2,14}=\right.$ $4.481, \mathrm{p}=0.03)$. Even when the number of spawned 

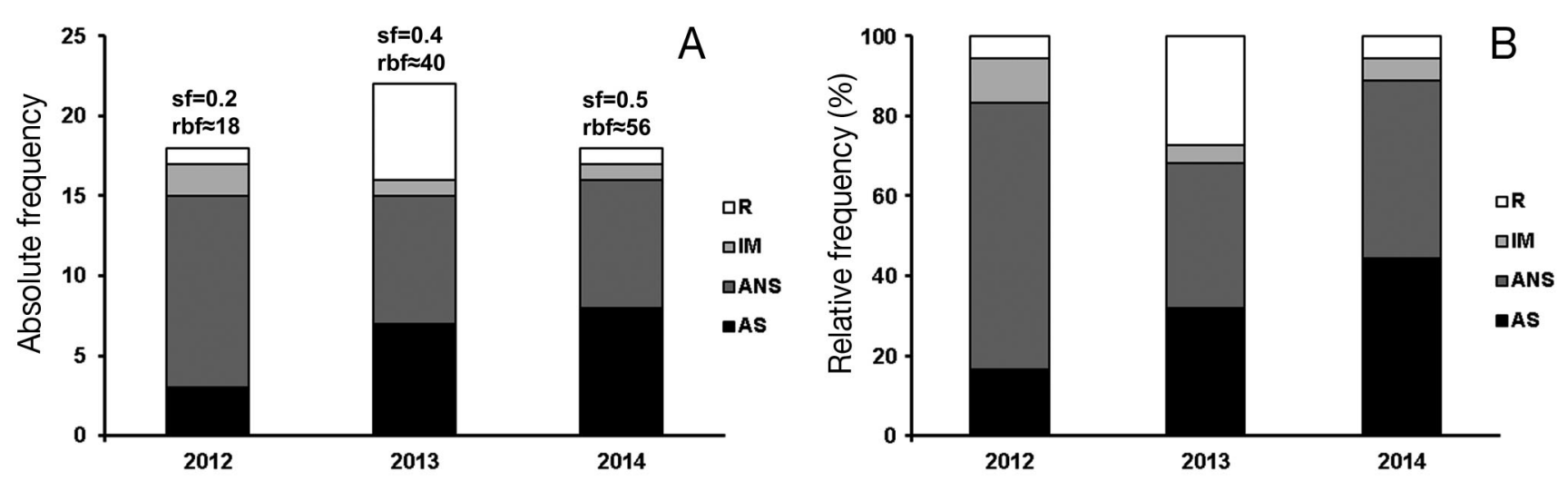

Fig. 4. (A) Absolute and (B) relative frequencies of the maturity stages found in Atlantic bluefin tuna Thunnus thynnus females sampled in 2012, 2013 and 2014. ANS: active nonspawning; AS: active spawning; IM: inactive mature; R: resting; rbf: relative batch fecundity $\left(\right.$ eggs $\left.\mathrm{g}^{-1}\right)$; sf: spawning fraction

eggs was calculated relative to the fish weight (mean $[ \pm \mathrm{SD}]$ relative batch fecundities of $17.89 \pm 10.40 \mathrm{~g}^{-1}$, $39.92 \pm 22.41 \mathrm{~g}^{-1}$ and $56.06 \pm 17.72 \mathrm{~g}^{-1}$, respectively, Fig. 4), the statistical analysis indicated significant differences, although the result of the test approached the limit of significance $\left(F_{2,14}=3.90, \mathrm{p}=0.045\right)$. For both absolute and relative fecundities, Tukey's HSD post hoc analysis showed that the fish sampled in 2012 were significantly less fecund than those sampled in 2014, whereas significant differences were not detected between the individuals from 2013 and the 2 other groups at a level of significance of 0.05 .

Linear regressions revealed significant relationships between the realised batch fecundity and FL, BW and GW, but the predictive capacity of the models was relatively poor. The best predictor of the batch fecundity was BW through the equation: $\mathrm{N}$ POF (realised batch fecundity) $=-4.51 \times 10^{6}+67.52 \times$ $10^{3} \mathrm{BW}\left(F_{1,15}=27.44, \mathrm{p}=0.0001, \mathrm{r}^{2}=0.62\right)$. Table 3 shows the values of Pearson's correlation coefficients of pairwise comparisons between variables. As seen in the table, relative batch fecundity was not significantly correlated with any of the variables considered.

\section{DISCUSSION}

ABFT schools caught by purse seining in the Balearic Sea have been observed to spawn in towing cages during their transportation to commercial facilities (Gordoa \& Carreras 2014). Our results show that farmed ABFT are also capable of spawning in commercial cages in subsequent years following their capture, even if the farm facility is relatively far from their natural spawning grounds. Histological evidence of spawning was observed between 9-11 June and 12-23 July. This period matches the reproductive peak reported previously for wild spawners in the western Mediterranean Sea (Heinisch et al. 2008, Gordoa \& Carreras 2014). Substantial oocyte resorption (IM reproductive stage) was identified from mid-July, leading to spent ovaries ( $\mathrm{R}$ stage) in late July to August. This temporal pattern is also consistent with the migratory dynamics revealed by electronic tagging in the region (Aranda et al. 2013a). Spawning occurred at SSTs ranging between 20 and $27^{\circ} \mathrm{C}$, but POFs were unexpectedly found in the ovaries of a fish sampled on 10 June 2013 at SST slightly over $17^{\circ} \mathrm{C}$, although the batch fecundity of this specimen was the lowest of all females examined. These observations support earlier results indicating that spawning may take place at SSTs well below the currently assumed minimum spawning temperature of $\sim 24^{\circ} \mathrm{C}$ (Gordoa \& Carreras 2014).

The fraction of spawning females appears to be lower in the captive environment than in the wild. A proportion of spawning females over $80 \%$ has been reported for ABFT breeding schools in the western Mediterranean Sea (Medina et al. 2002, 2007, Aranda et al. 2013a,b). In contrast, only 3 of the captive females sampled in 2012 were classified as AS, representing $20 \%$ of the total number of individuals found in the spawning-capable phase sensu Brown-Peterson et al. (2011), i.e. ANS plus AS fish. The spawning fraction was substantially greater in the samples of the 2 other years, where the percentage of AS females related to the total spawning-capable fish was $40 \%$ in the sample of 2013 and $50 \%$ in 2014. Such differences could be due to the smaller size of the fish in the 2012 group, but the effect of size/age on spawning fraction requires further investigation to draw reliable conclusions. 
Table 3. Output of bivariate correlation analysis between the continuous variables considered in the study showing values for Pearson's correlation coefficient $r$. BW: body weight; FL: straight fork length; GW: ovarian weight; GSI: gonadosomatic index;

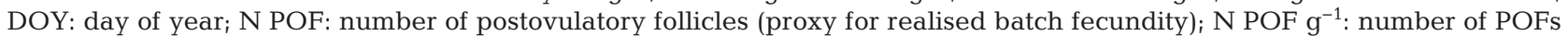
per gram of total body weight (proxy for relative realised batch fecundity); SST: sea surface temperature. Correlations were significant at ${ }^{*} \mathrm{p}<0.05$ and ${ }^{* *} \mathrm{p}<0.01$

\begin{tabular}{|c|c|c|c|c|c|c|c|}
\hline & N POF $g^{-1}$ & FL & BW & GW & GSI & DOY & SST \\
\hline N POF & $0.843^{* *}$ & $0.662^{* *}$ & $0.804^{* *}$ & $0.746^{* *}$ & 0.351 & -0.087 & -0.087 \\
\hline $\mathrm{N} \mathrm{POF} \mathrm{g}^{-1}$ & & 0.360 & 0.441 & 0.474 & 0.409 & -0.053 & 0.015 \\
\hline FL & & & $0.911^{* *}$ & $0.865^{* *}$ & $0.497^{*}$ & -0.270 & -0.266 \\
\hline BW & & & & $0.922^{* *}$ & 0.383 & -0.256 & -0.311 \\
\hline GW & & & & & $0.686^{* *}$ & -0.431 & -0.324 \\
\hline GSI & & & & & & $-0.547^{*}$ & -0.232 \\
\hline DOY & & & & & & & $0.824^{* *}$ \\
\hline
\end{tabular}

The POF size and morphology varied among individuals, indicating they had different ages (see Aragón et al. 2010). Since all harvests were performed within a narrow time range early in the morning, distinct POF morphologies could reflect an irregular temporal spawning pattern in the cages. This is consistent with observations of spawning at different hours of the day (pers. comm. from the farm staff). In the wild, conversely, spawning appears to take place at nighttime within a narrow temporal window, approximately between 12:00 and 03:00 h UTC (Gordoa et al. 2009, Aranda et al. 2013a, Gordoa \& Carreras 2014).

Preceding studies on experimental ABFT broodstocks (Corriero et al. 2007, Aranda et al. 2011) found that the spawning fraction in cages was low (similar to our 2012 data) even after a 3 yr period of adaptation to captivity. In ABFT, as in other teleosts, the stressful captive environment causes reproductive dysfunctions that primarily include oocyte maturation and ovulation failure in females, and reduced sperm quality/quantity in males (Mylonas et al. 2007). Although previous experimental trials have shown poor egg production in captive ABFT compared to wild populations, our observations suggest that a substantial proportion of ABFT held in farm grow-out cages are functional spawners during the species' natural reproductive season.

The increasing aquaculture of fish species, such as cod or sea bream, until the reproductive age results in escapes of large numbers of eggs into the environment (Uglem et al. 2012, Somarakis et al. 2013). The ABFT, like the Pacific bluefin tuna, is an example of those species where so-called 'escape through spawning' (Uglem et al. 2012) may be significant in commercial facilities, since $>60 \%$ of the ABFT eastern stock total allowable catch ends up in Mediterranean tuna farms (Ortiz 2015). We know that ABFT eggs collected from grow-out cages show a high hatching rate $(75-87 \%)$ and produce apparently healthy yolk-sac larvae at temperatures between 21 and $26^{\circ} \mathrm{C}$ (Ortega 2015). However, the number and quality of the eggs produced in farms are difficult to determine, as it is virtually impossible to make sure that the entire spawns are collected from offshore cages.

Nevertheless, while reliable direct estimations of numbers of spawned eggs are unfeasible, the occurrence of POFs is useful to estimate the spawning fraction of females (Hunter \& Macewicz 1985b, Hunter et al. 1986, Ganias 2012), and the quantification of these structures from histological samples provides accurate measures of fecundity. POFs are not detectable for more than $24 \mathrm{~h}$ in tuna species, such as the ABFT, that spawn in warm waters (Schaefer 2001). Thus, the number of eggs spawned within the past $24 \mathrm{~h}$ by ABFT can be estimated from unbiased stereological counts of POFs in ovarian samples (Aragón et al. 2010, Ganias et al. 2014). The average batch fecundity estimated for AS females in 2012 was $~ 2$ million eggs (relative batch fecundity $\sim 18$ eggs ${ }^{-1}$ ), which is far below the estimates for the 2 other years: 8.5 and

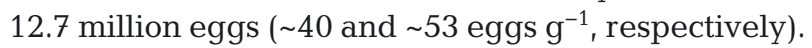
The 2 latter figures are similar to the fecundities calculated elsewhere for captive and wild ABFT using the same counting technique (Aranda et al. 2011). In agreement with a previous study conducted on wild ABFT (Aranda et al. 2013b), the absolute batch fecundity was strongly correlated with fish size, expressed as both FL and BW. However, the relative batch fecundity was not dependent on fish size, so that, generally speaking, all fish would contribute to the number of eggs produced by the broodstock in proportion to their weight. Consequently, the daily egg production of a stock could be easily estimated from data of the biomass stocked in the cages, the 
sex ratio of the stock and the estimates of spawning fraction and relative realised batch fecundity. For instance, the proportion of spawning females found in this study was $\sim 0.3$ (17 fish with POFs out of 58 females sampled in all 3 years, Table 1). Assuming a batch fecundity of 50 eggs $\mathrm{g}^{-1}$, a sex ratio of 1:1 and equal sizes in males and females, a sea-cage holding $100 \mathrm{t}$ of mature ABFT would produce as many as $\sim 750$ million eggs daily. Estimations of total annual egg production in tuna farms would need accurate data on the average duration of the spawning period, which still remains to be determined in captivity conditions. Current progress in genetic analysis (e.g. Nakadate et al. 2011, Gordoa et al. 2015), however, is promising for the estimation of key reproductive parameters in bluefin tunas, including individual spawning duration in captivity.

Jensen et al. (2013) showed that Atlantic salmon escaped from farms at the smolt stage or early in the post-smolt stage may grow, migrate and survive to adulthood as wild specimens do. A similar situation may occur with ABFT larvae hatched in farms. The productive coast off the Ebro River delta, where the studied farm is located, is used as a feeding habitat by early stages of ABFT (about 3-4 mo old) coming from the breeding grounds around the Balearic archipelago (Medina et al. 2015). Although the survival rate from hatching to age $3 \mathrm{mo}$ in this area is unknown, some of the larvae hatched from eggs spawned in the farm are likely to grow and join wild-born young ABFT in the nearby feeding ground. The same may hold true for other Mediterranean farms located close to age-0 ABFT feeding areas. This could have an impact on the recruitment and hence on the population dynamics of ABFT in the Mediterranean Sea. In order to assess the survivorship of ABFT larvae, ongoing experimental work is being conducted to investigate the temperature tolerances of ABFT larval and postlarval stages.

Depending on the number of fish that are ranched for over 1 yr and the larval survival rate in the zone, the 'escape through spawning' phenomenon could have significant ecological implications and, hence, warrant further investigation regarding population dynamics and stock assessment.

Acknowledgements. This work was funded by the Spanish Ministry of Economy and Competitiveness (contract no. AGL2014-52003-C2-1-R). It would not have been possible without the collaboration and advice from the owners and staff of Grup Balfegó. This is contribution no. 113 of CEI.MAR.

\section{LITERATURE CITED}

Aragón L, Aranda G, Santos A, Medina A (2010) Quantification of ovarian follicles in bluefin tuna Thunnus thynnus by two stereological methods. J Fish Biol 77:719-730

Aranda G, Aragón L, Corriero A, Mylonas CC, de la Gándara F, Belmonte A, Medina A (2011) GnRHa-induced spawning in cage-reared Atlantic bluefin tuna: an evaluation using stereological quantification of ovarian postovulatory follicles. Aquaculture 317:255-259

Aranda G, Abascal FJ, Varela JL, Medina A (2013a) Spawning behaviour and post-spawning migration patterns of Atlantic bluefin tuna (Thunnus thynnus) ascertained from satellite archival tags. PLoS ONE 8:e76445

Aranda G, Medina A, Santos A, Abascal FJ, Galaz T (2013b) Evaluation of Atlantic bluefin tuna reproductive potential in the western Mediterranean Sea. J Sea Res 76:154-160

Arechavala-López P, Borg JA, Šegvić-Bubić T, Tomassetti P, Özgül A, Sánchez-Jerez P (2015) Aggregations of wild Atlantic bluefin tuna (Thunnus thynnus L.) at Mediterranean offshore fish farm sites: environmental and management considerations. Fish Res 164:178-184

Brown-Peterson NJ, Wyanski DM, Saborido-Rey F, Macewicz BJ, Lowerre-Barbieri SK (2011) A standardized terminology for describing reproductive development in fishes. Mar Coast Fish 3:52-70

Corriero A, Karakulak S, Santamaria N, Deflorio M and others (2005) Size and age at sexual maturity of female bluefin tuna (Thunnus thynnus L. 1758) from the Mediterranean Sea. J Appl Ichthyol 21:483-486

> Corriero A, Medina A, Mylonas CC, Abascal FJ and others (2007) Histological study of the effects of treatment with gonadotropin-releasing hormone agonist (GnRHa) on the reproductive maturation of captive-reared Atlantic bluefin tuna (Thunnus thynnus L.). Aquaculture 272:675-686

Corriero A, Medina A, Mylonas CC, Bridges CR and others (2009) Proliferation and apoptosis of male germ cells in captive Atlantic bluefin tuna (Thunnus thynnus L.) treated with gonadotropin-releasing hormone agonist (GnRHa). Anim Reprod Sci 116:346-357

De la Gándara F, Mylonas CC, Coves D, Ortega A and others (2010) Seedling production of Atlantic bluefin tuna (ABFT) Thunnus thynnus, the SELFDOTT project. In: Miyashita S, Takii K, Sakamoto W, Biswas A (eds) Towards the sustainable aquaculture of bluefin tuna. Proc Int Symp $40^{\text {th }}$ Anniv Pacific Bluefin Tuna Aquacult. Kinki University Press, Kinki, p 45-52

De Metrio G, Bridges CR, Mylonas CC, Caggiano $M$ and others (2010) Spawning induction and large-scale collection of fertilized eggs in captive Atlantic bluefin tuna (Thunnus thynnus L.) and the first larval rearing efforts. J Appl Ichthyol 26:596-599

Ganias K (2012) Thirty years of using the postovulatory follicles method: overview, problems and alternatives. Fish Res 117-118:63-74

Ganias K, Murua H, Claramunt G, Dominguez-Petit R and others (2014) Egg production. In: Domínguez-Petit R, Murua H, Saborido-Rey F, Trippel E (eds) Handbook of applied fisheries reproductive biology for stock assessment and management. Northwest Atlantic Fisheries Organization, Vigo. Available at http://hdl.handle.net/10261/87768

Gordoa A, Carreras G (2014) Determination of temporal spawning patterns and hatching time in response to temperature of Atlantic bluefin tuna (Thunnus thynnus) in the western Mediterranean. PLoS ONE 9:e90691

Gordoa A, Olivar MP, Arévalo R, Viñas J, Molí B, Illas X (2009) Determination of Atlantic bluefin tuna (Thunnus 
thynnus) spawning time within a transport cage in the western Mediterranean. ICES J Mar Sci 66:2205-2210

Gordoa A, Sanz N, Viñas J (2015) Individual spawning duration of captive Atlantic bluefin tuna (Thunnus thynnus) revealed by mitochondrial DNA analysis of eggs. PLoS ONE 10:e0136733

Gutiérrez M (1967) Coloración histológica para ovarios de peces, crustáceos y moluscos. Invest Pesq (Spain) 31: 265-271

Heinisch G, Corriero A, Medina A, Abascal FJ and others (2008) Spatial-temporal pattern of bluefin tuna (Thunnus thynnus L. 1758) gonad maturation across the Mediterranean Sea. Mar Biol 154:623-630

Hunter JR, Macewicz BJ (1985a) Rates of atresia in the ovary of captive and wild northern anchovy, Engraulis mordax. Fish Bull 83:119-136

Hunter JR, Macewicz BJ (1985b) Measurement of spawning frequency in multiple spawning fishes. In: Lasker R (ed) An egg production method for estimating spawning biomass of pelagic fish: application to the northern anchovy, Engraulis mordax. NOAA Tech Rep NMFS 36:79-94

Hunter JR, Macewicz BJ, Sibert JR (1986) The spawning frequency of skipjack tuna, Katsuwonus pelamis, from the South Pacific. Fish Bull 84:895-903

> Jensen AJ, Karlsson S, Fiske P, Hansen LP, Hindar K, Østborg GM (2013) Escaped farmed Atlantic salmon grow, migrate and disperse throughout the Arctic Ocean like wild salmon. Aquacult Environ Interact 3:223-229

Knapp JM, Aranda G, Medina A, Lutcavage M (2014) Comparative assessment of the reproductive status of female Atlantic bluefin tuna from the Gulf of Mexico and the Mediterranean Sea. PLoS ONE 9:e98233

Mangion M, Borg JA, Thompson R, Schembri PJ (2014) Influence of tuna penning activities on soft bottom macrobenthic assemblages. Mar Pollut Bull 79:164-174

> Medina A, Abascal FJ, Megina C, García A (2002) Stereological assessment of the reproductive status of female Atlantic northern bluefin tuna during migration to Mediterranean spawning grounds through the Strait of Gibraltar. J Fish Biol 60:203-217

- Medina A, Abascal FJ, Aragón L, Mourente G and others (2007) Influence of sampling gear in assessment of reproductive parameters for bluefin tuna in the western Mediterranean. Mar Ecol Prog Ser 337:221-230

> Medina A, Goñi N, Arrizabalaga H, Varela JL (2015) Feeding patterns of age-0 bluefin tuna in the western Mediterranean inferred from stomach-content and isotope analyses. Mar Ecol Prog Ser 527:193-204

Metian M, Pouil S, Boustany A, Troell M (2014) Farming of bluefin tuna -reconsidering global estimates and sustainability concerns. Rev Fish Sci Aquacult 22:184-192

> Moraitis M, Papageorgiou N, Dimitriou PD, Petrou A, Karakassis I (2013) Effects of offshore tuna farming on benthic assemblages in the Eastern Mediterranean. Aquacult Environ Interact 4:41-51

Mylonas CC, Bridges CR, Gordin H, Belmonte Ríos A and others (2007) Preparation and administration of gonadotropin-releasing hormone agonist (GnRHa) implants for the artificial control of reproductive maturation in captive-reared Atlantic bluefin tuna (Thunnus thynnus thynnus). Rev Fish Sci 15:183-210

Mylonas CC, de la Gándara F, Corriero A, Belmonte Ríos A (2010) Atlantic bluefin tuna (Thunnus thynnus) farming and fattening in the Mediterranean Sea. Rev Fish Sci 18:266-280

Nakadate M, Kusano T, Fushimi H, Kondo H, Hirono I, Aoki $\mathrm{T}$ (2011) Multiple spawning of captive Pacific bluefin tuna (Thunnus orientalis) as revealed by mitochondrial
DNA analysis. Aquaculture 310:325-328

Ortega A (2015) Cultivo integral de dos especies de escómbridos: atún rojo del Atlántico (Thunnus thynnus, L. 1758) y bonito Atlántico (Sarda sarda, Bloch 1793). PhD dissertation, University of Murcia

Ortiz M (2015) Preliminary evaluations of potential growth of fattened/farmed eastern bluefin tuna (Thunnus thynnus) from ICCAT farm size database. Col Vol Sci Pap ICCAT 71:1505-1525

Ottolenghi F (2008) Capture-based aquaculture of bluefin tuna. In: Lovatelli A, Holthus PF (eds) Capture-based aquaculture, Vol 508. Food and Agriculture Organization of the United Nations, Rome, p 169-182

Piedecausa MA, Aguado-Giménez F, Cerezo-Valverde J, Hernández-Llorente MD, García-García B (2010) Simulating the temporal pattern of waste production in farmed gilthead seabream (Sparus aurata), European seabass (Dicentrarchus labrax) and Atlantic bluefin tuna (Thunnus thynnus). Ecol Model 221:634-640

R Core Team (2015) R: a language and environment for statistical computing. R Foundation for Statistical Computing, Vienna. www.R-project.org/

Rosenfeld H, Mylonas CC, Bridges CR, Heinisch G and others (2012) GnRHa-mediated stimulation of the reproductive endocrine axis in captive Atlantic bluefin tuna, Thunnus thynnus. Gen Comp Endocrinol 175:55-64

Sarà G, Lo Martire M, Sanfilippo M, Pulicanò G and others (2011) Impacts of marine aquaculture at large spatial scales: evidences from $\mathrm{N}$ and $\mathrm{P}$ catchment loading and phytoplankton biomass. Mar Environ Res 71:317-324

> Sawada Y, Seoka M, Kato K, Tamura T and others (2007) Testes maturation of reared Pacific bluefin tuna Thunnus orientalis at two-plus years old. Fish Sci 73:1070-1077

Schaefer KM (1998) Reproductive biology of yellowfin tuna (Thunnus albacares) in the eastern Pacific Ocean. InterAm Trop Tuna Comm Bull 21:201-272

Schaefer KM (2001) Reproductive biology of tunas. In: Block BA, Stevens ED (eds) Tuna: physiology, ecology and evolution. Academic Press, London, p 225-270

Seoka M, Kato K, Kubo T, Mukai Y, Sakamoto W, Kumai H, Murata O (2007) Gonadal maturation of Pacific bluefin tuna Thunnus orientalis in captivity. Aquacult Sci 55:289-292

> Somarakis S, Pavlidis M, Saapoglou C, Tsigenopoulos CS, Dempster T (2013) Evidence for 'escape through spawning' in large gilthead sea bream Sparus aurata reared in commercial sea-cages. Aquacult Environ Interact 3:135-152

> Sterio DC (1984) The unbiased estimation of number and sizes of arbitrary particles using the disector. J Microsc 134:127-136

Sumaila UR, Huang L (2012) Managing bluefin tuna in the Mediterranean Sea. Mar Policy 36:502-511

$>$ Uglem I, Knutsen $\varnothing$, Kjesbu OS, Hansen $\varnothing \mathrm{J}$ and others (2012) Extent and ecological importance of escape through spawning in sea-cages for Atlantic cod. Aquacult Environ Interact 3:33-49

> Vezzulli L, Moreno M, Marin V, Pezzati E, Bartoli M, Fabiano M (2008) Organic waste impact of capture-based Atlantic bluefin tuna aquaculture at an exposed site in the Mediterranean Sea. Estuar Coast Shelf Sci 78: 369-384

Vitalini V, Benetti D, Caprioli R, Forrestal F (2010) Northern bluefin tuna (Thunnus thynnus thynnus) fattening in the Mediterranean Sea: status and perspectives. World Aquacult 41:30-36

> Vizzini S, Mazzola A (2012) Tracking multiple pathways of waste from a northern bluefin tuna farm in a marinecoastal area. Mar Environ Res 77:103-111 